\title{
Importance of hypocotyl hairs in germination of Artemisia seeds
}

JAMES A. YOUNG AND ELLEN MARTENS

\begin{abstract}
The nature and function of hairs that occur on the lower portion of the hypocotyl of juvenile Artemisia seedlings was investigated. Our purpose was to determine if these hairs served an important function in seedling establishment of these species, which are often difficult to establish by direct seeding. The hypocotyl hairs occurred in a number of Artemisia species. The hairs form a dense ring around the bottom of the hypocotyl and the radicle emerges through the ring. Apparently, the function of the hairs is to attach the juvenile seedling to the surface of the germination substrate, which may aid in the penetration of the radicle into the substrate. Scanning electron microscope images of the hypocotyl hairs revealed the occurrence of mucilage which may aid in attaching the hairs to the substrate. In most studies, dislodging the seedling and breaking the contact of the hypocotyl hairs to the substrate reduced seedling survival and increased the number of surviving seedlings with abnormal geotropism.
\end{abstract}

Key Words: seedbed ecology, seedling morphology, geotropism, seedling stress

Many seeds have chemical or physical appendages located external to the seed or fruit coat that aid in seedling establishment. E.J. Salisbury devoted an entire book manuscript to describing unique adaptations of seeds that aid in seedling establishment (Salisbury 1942). Self burial using hygroscopically powered, sharply bent awns or styles as in the case of species of Erodium is an example of an external mechanical aid (Young et al. 1975). In some grass caryopses the awns can be tiny in size, but still highly efficient in action, as in the case of silver hairgrass (Aira caryophyllea) (Evans et al. 1974). Seeds and fruits produce a wide array of types of mucilage, the function of which has been attributed to serve as protection against predation, a means of long distance dispersal, a means of orientation of seeds on seedbed, and among others as a glue to hold seeds to seedbeds (Young and Evans 1973). In arid and semiarid environments, external mucilage apparently is an important factor in the moisture relations of seeds germinating on the surface of seedbeds (Young et al. 1970).

The artificial establishment of big sagebrush (Artemisia tridentata) by direct seeding is difficult despite the natural occurrence of this species over vast areas of rangelands in western North America. The achenes of big sagebrush are quite small, roughly 1.5 by 1.0 $\mathrm{mm}$, and seedling establishment is highest when the small seeds are planted at or close to the soil surface (Jacobson and Welch 1987). There are 2 aspects of moisture relations that become critical for seeds germinating from the surface of the seedbed in semiarid environments. The seed must take up moisture from the substrate faster than it is lost to the atmosphere (Harper et al. 1965), and secondly the seedling radicle must penetrate the substrate and begin taking up moisture as soon as possible (Wallace et al. 1968). The achenes of big sagebrush are not truly mucilaginous, but the achene coat becomes gelatinous when imbibed, which may aid moisture relations. The small size of big sagebrush achenes reduces surface area for moisture loss and the relative density and shape of the achenes aid in self burial in some surface soils through winnow-

\footnotetext{
Authors are range scientist and binchemist research technician, respectively USDA-ARS, Reno, Nevada 89512

The authors gratefully acknowledge the assistance of Drs. E. Durant McArthur and Susan Meyer for furnishing Artemisia seed, and Karen McCoy of the Dept. of Anatomy, University of Nevada School of Medicine, for the SEM work.

Manuscript accepted 19 October 1990.
}

ing (Young et al. 1990).

Detailed studies of artificial planting of big sagebrush achenes have established that the relative hardness or resistance to penetration of the surface of the seedbed is an important factor in seedling establishment (Young et al. 1990). This apparently relates to the ease and rapidity of penetration of the radicle and initial uptake of moisture as described by Wallace et al. (1968) for Salsola seedlings.

We noted during macro-photographic studies of big sagebrush seedlings that the embryonic plants rapidly develop hypocotyl hairs during the initial phase of germination. Hypocotyl hairs have been reported for seedlings in several families, but not to our knowledge for Artemisia seedlings. Hypocotyl hairs have been studied in species of Populus where they are thought to be important in seedling geotropism (Polya 1961). Populus seedlings with vigorous hypocotyl hairs have been observed to have a better chance of seedling establishment than seedling with weak or damaged hairs.

Our purpose was to investigate the nature and function of hypocotyl hairs on seedlings of the Artemisia species.

\section{Materials and Methods}

\section{Nature of Hairs}

Artemisia seeds were incubated at $15^{\circ} \mathrm{C}$ in closed petri dishes on damp germination paper. Various colors of nontoxic paper were tried to enhance contrast with the hairs. As soon as the achene coat split and the embryonic plant was visible, the radicle and hypocotyl portion of the embryonic plant were observed under a light microscope. The hairs were stained with methylene blue for contrast. Seeds of 3 subspecies of big sagebrush: mountain (Artemisia tridentata subsp. vaseyana), basin (A. tridentata subsp. tridentata), and Wyoming (A.tridentata subsp. wyomingensis); low sagebrush (A. arbuscula); and black sagebrush ( $A$. nova) were obtained from stands in the western Great Basin. Seeds of these species plus seeds of Bigelow sagebrush (A. bigelovii), A. dracunculus, A. ludoviciana, $A$. filifolia, and $A$. vulgaris were obtained from the Shrub Sciences Laboratory, Forest Service, USDA, Provo, Utah.

Artemisia achenes with the base of the hypocotyl emerging were frozen by immersion in liquid nitrogen and prepared for examination by scanning electron microscopy (SEM). Scanning electron microscope comparisons were made of root hairs versus hypocotyl hairs. The length and width of hypocotyl hairs were calculated by measuring their size on the SEM print and negative with a $\mathrm{mm}$ ruler. The size in the print divided by the size in the negative times the magnification of the scanning electron microscope gives the magnification of the print. The size of the hair in the print divided by the magnification of the print gives the actual size of the hair.

Basin big sagebrush seeds were planted in moist fine sand with either the callus or pappus end of the achene down and incubated at $25^{\circ} \mathrm{C}$. Individual seeds were observed during the germination process to determine the influence of achene orientation on hypocotyl hair and seedling development.

The phenology of germination of basin big sagebrush seeds was determined at $10,15,20,25$, and $30^{\circ} \mathrm{C}$ incubation temperatures. Seedling phenology was recorded on 3 substrates: fine sand, 60 mesh; coarse sand, 100 mesh; and germination paper. Phenological stages recorded were emergence of base of embryonic plant, hypo- 


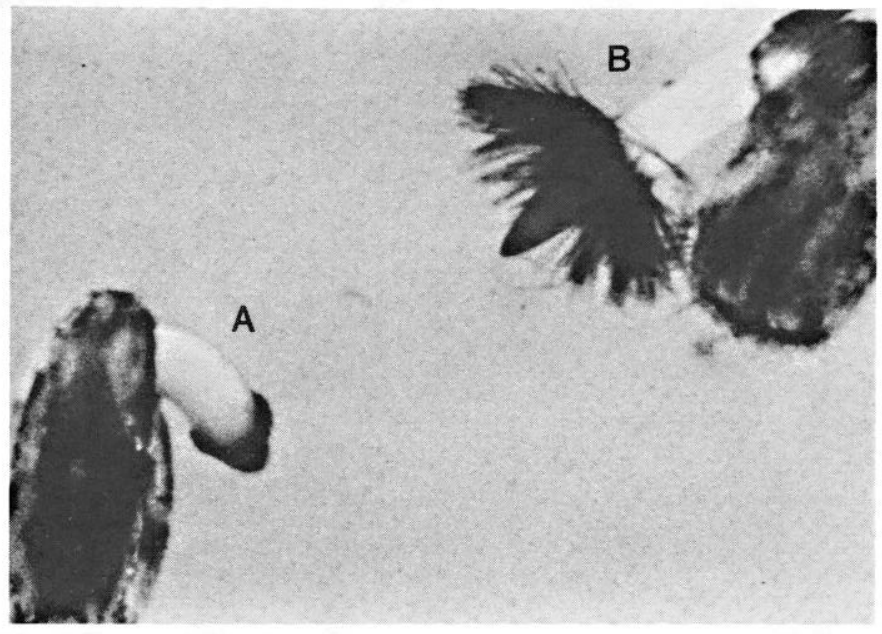

Fig. 1. Very juvenile seedling of basin big sagebrush showing: (A) down curved hypocotyl with beginning of initiation of hypocotyl hairs: (B) slightly more developed seedling with abundant hypocotyl hairs (light microscope 32X).

cotyl hairs form, hypocotyl hairs attach to substrate, hypocotyl arch straightens, radicle elongates, and cotyledons spread with achene coat shed.

\section{Function of Hypocotyl Hairs}

Basin big sagebrush and low sagebrush seeds were placed in closed petri dishes on germination paper, fine sand, and coarse sand. Each substrate received 100 seeds of each species with 4 replications in a randomized block design. To simulate seedbed disturbance, seedlings with the hypocotyl hairs attached to the substrate were picked up and transferred to a different container with the same substrate. Both the original and transfer substrates were moistened with tap water. The original and transfer containers were incubated at $20^{\circ} \mathrm{C}$. The survival and tropism of the transferred seedling were recorded.

A two-way randomized complete block design was utilized for the analysis. Hartley's F-max test for homogeneity of variance was first performed and no transformation of the percentage data was necessary. After a significant F-test result in the ANOVA design, Duncan's New Multiple Range Test was performed as the multiple comparison technique.

Basin big sagebrush and low sagebrush seeds were placed on germination paper in closed petri dishes and moistened with tap water. The same experimental design and procedures as above were used. After the hypocotyl hairs were developed, seedlings were transferred to dry plates with paper substrate. After 5, 15, or 60 minutes drying at $25^{\circ} \mathrm{C}$, the seedlings were moistened and survival and geotropism recorded.

Hartley's F-max test for homogeneity of variance was utilized and no transformation of percent survival and normal seedling tropism was necessary. A one-way randomized complete block analysis of variance was then performed with significant F-tests resulting in the Duncan's New Multiple Range Test being performed.

Basin big sagebrush seeds were placed on germination paper in closed petri dishes and incubated at $20^{\circ} \mathrm{C}$ using the same design as above. After seedling germinated and the hypocotyl hairs became attached to the substrate, the seedlings were transferred to plates where the osmotic potential of the substrate was maintained at 0 , $-0.03,-0.3,-0.6 \mathrm{MPa}$ with appropriate solutions of polyethylene glycol (PEG) M.W. 6,000 (Michel et al. 1973). The survival and tropism of seedlings were recorded.

Hartley's F-max test was again utilized and no transformation of

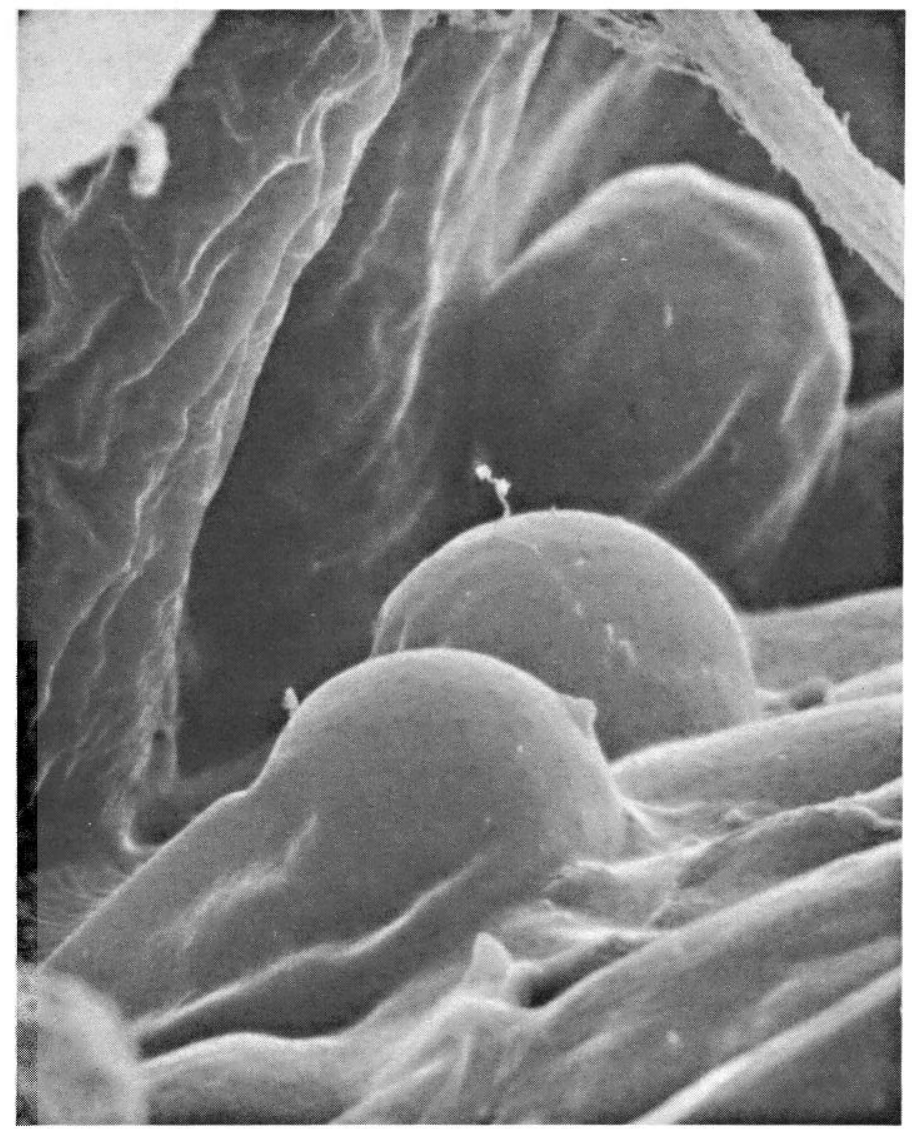

Fig. 2. SEM showing apparent elongation of hypocotyl hairs of big sagebrush seedlings from single epidermal cells (3640X).

percent survival, normal geotropism, and negative geotropism was found to be necessary. A one-way randomized complete block analysis of variance was then performed for each of the above 3 dependent variables. Significant F-test results led to the use of Duncan's New Multiple Range Test as the multiple comparison procedure.

\section{Results and Discussion}

The seedlings of all species of Artemisia tested developed hypocotyl hairs. There were differences in density, length, and slight color changes in the hypocotyl hairs among species. The hairs were located in a uniform, compact ring at the extreme base of the hypocotyl (Fig. 1). Scanning electron microscopic examination of the hypocotyl revealed the apparent development of the hairs from a single epidermal cell (Fig. 2). Fully developed hairs are approximately 0.007-0.01 $\mathrm{mm}$ in diameter and 0.66-0.90 $\mathrm{mm}$ long (Fig. 3). The developing hypocotyl hairs are covered with flakes of material that develop into mucilage (Fig. 4). In contrast, root hairs are smooth (Fig. 5). By the time the hypocotyl arch is raised, the hairs appear to be anchoring the seedling to the substrate (Fig. 6). The hypocotyl hairs disappear as the seedlings become older. They do not develop into a root system. The direction of orientation of the achene in planting in fine sand did not have a significant $(P \leq 0.01)$ influence on the ultimate development basin big sagebrush seedlings (data not shown). Planting the achenes with the top end down did illustrate that the lower portion of the hypocotyl had positive tropism. The hypocotyl emerged from the split achene coat and bent in a tight $U$ to the soil surface where the ring of hairs spread to the sand particles of the surface of the substrate. The top 


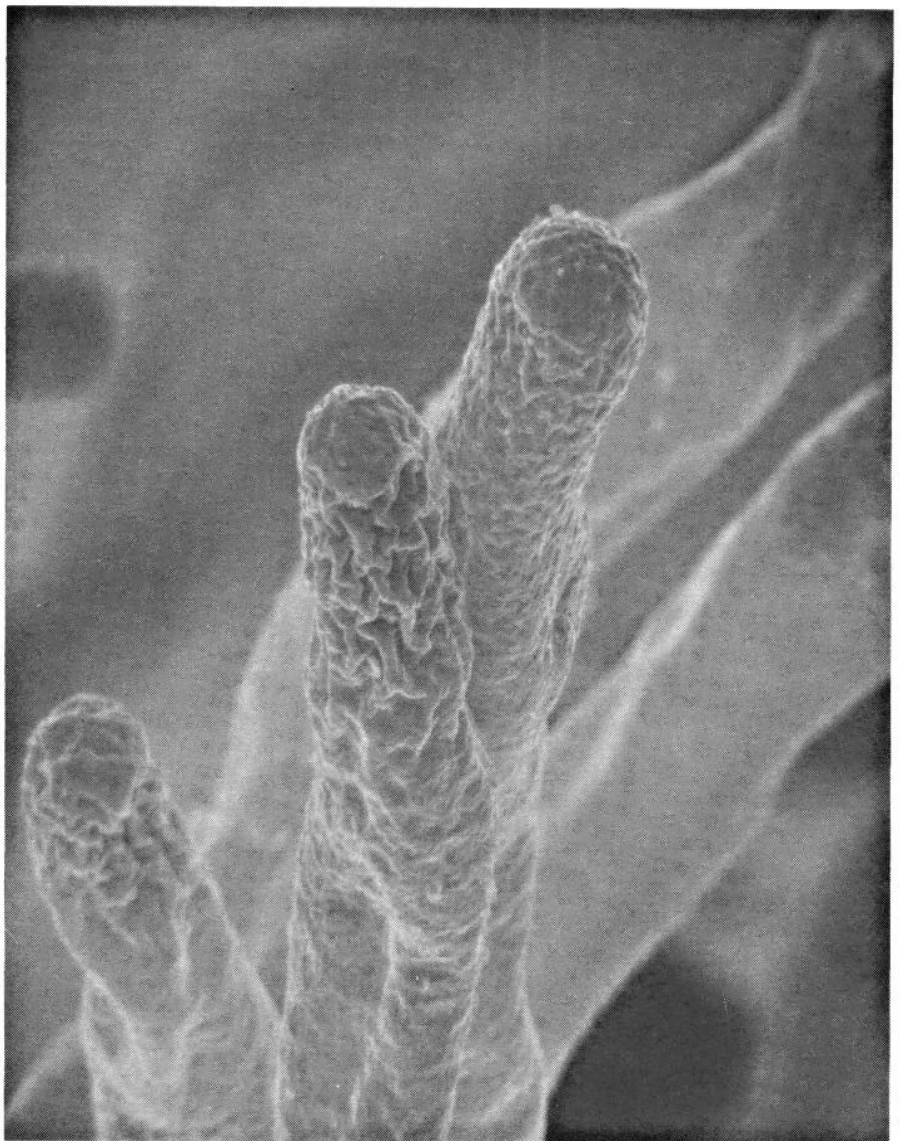

Fig. 3. SEM of hypocotyl hairs of big sagebrush showing rough surface (2500X).

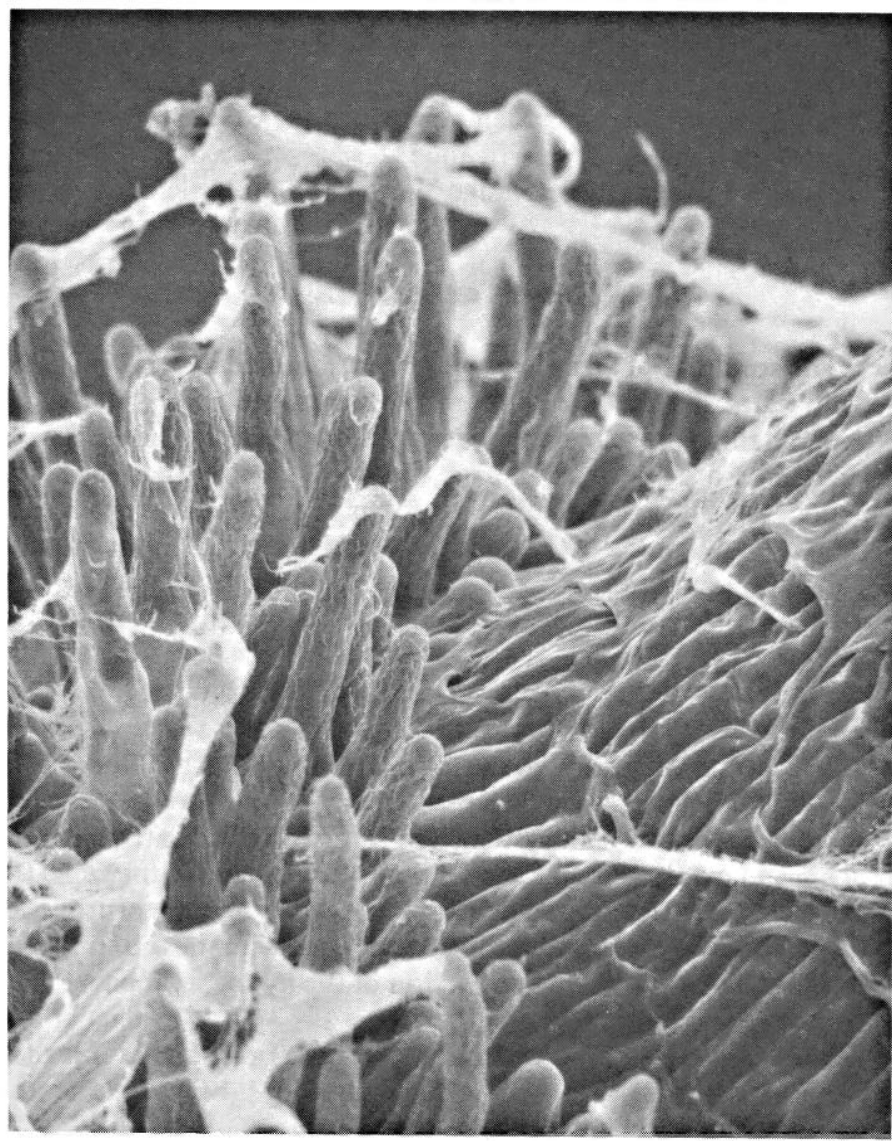

Fig. 4. SEM of ring of hypocotyl hairs of big sagebrush showing apparent mucilage (540X)

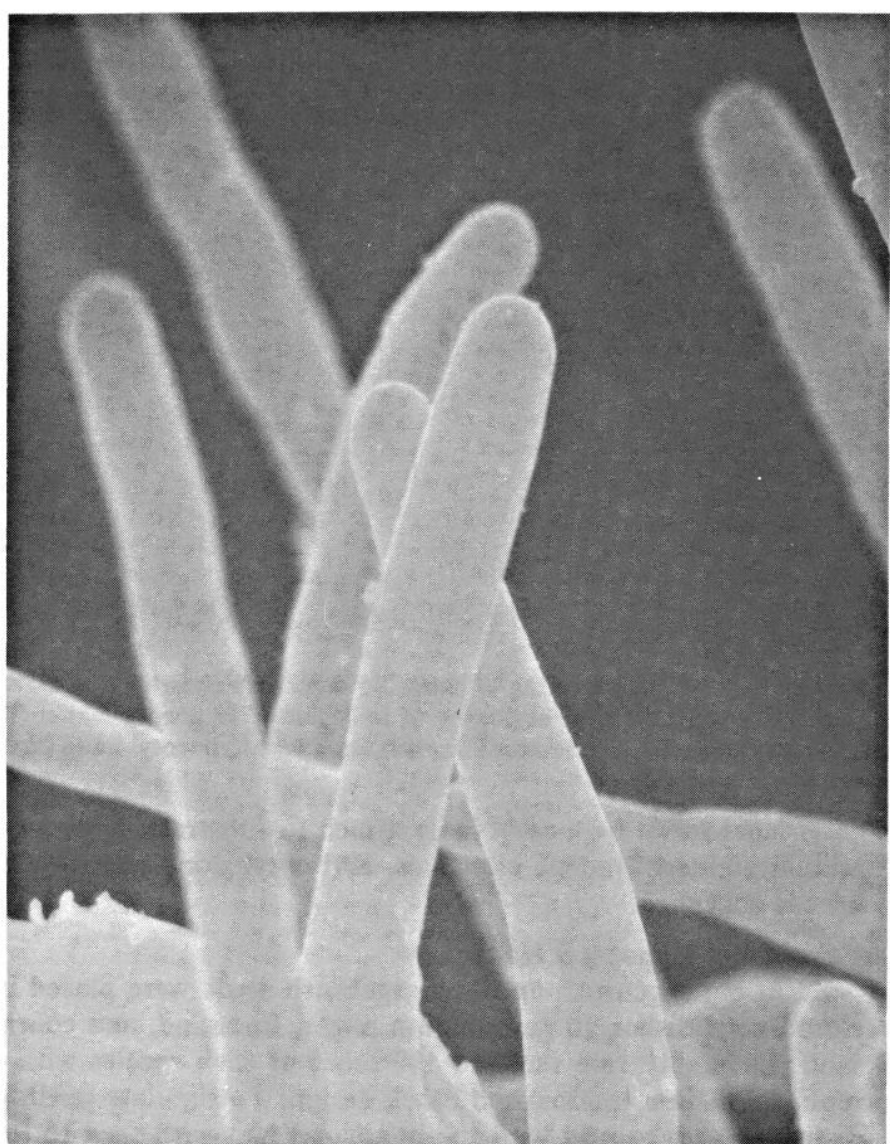

Fig. 5. SEM of root hair of big sagebrush showing relative smooth surface (1660X).

portion of the hypocotyl developed negative tropism, lifting the cotyledons and freeing them from the achene coat.

The phenology of basin big sagebrush seed germination is quite rapid (Table 1). Slightly more than 24 hours of incubation at $25^{\circ} \mathrm{C}$ resulted in the lower portion of the hypocotyl and radicle emerging

Table 1. Phenological stages in germination and growth rate of radicle and hypocotyl of basin big sagebrush on fine or coarse sand or germination paper when incubated at $25^{\circ} \mathrm{C}$.

\begin{tabular}{|c|c|c|c|}
\hline \multirow[b]{3}{*}{ Phenological stages } & \multicolumn{3}{|c|}{ Development } \\
\hline & \multicolumn{3}{|c|}{ Substrates } \\
\hline & Fine sand & Coarse sand & $\begin{array}{c}\text { Germination } \\
\text { paper }\end{array}$ \\
\hline & \multicolumn{3}{|c|}{ - $\ldots \ldots$ - } \\
\hline Radicle emerged & 25 & 25 & 26 \\
\hline Hypocotyl hairs formed & 25 & 28 & 28 \\
\hline Hypocotyl arch straightened & $32-54$ & $32-54$ & $34-54$ \\
\hline Cotyledons spread & $27-36$ & $28-56$ & $34-54$ \\
\hline Radicle growth & $\ldots \ldots$ & $\ldots \mathrm{mm}-.$. & . . \\
\hline 54 hours & 2 & 5 & 3 \\
\hline 78 hours & 6 & 5 & 6 \\
\hline 102 hours & 8 & 5 & 6 \\
\hline \multicolumn{4}{|l|}{ Hypocotyl growth } \\
\hline 54 hours & 3 & 6 & 3 \\
\hline 78 hours & 7 & 10 & 6 \\
\hline 102 hours & 9 & 11 & 10 \\
\hline
\end{tabular}

from the achene coat. This phenological stage is preceded by elongation or stretching of the achene. As previously mentioned, the achene coat became gelatinous with imbibition. In some cases the hypocotyl hairs appear to be present before the achene coat 
ruptures. The later the phenological stage in initial seedling development during the germination process, the more variability in the seed population (Table 1). The cotyledons of big sagebrush can spread before the hypocotyl arch is raised in contrast to seedlings of Kochia where the arch always rises first (Young et al. 1981). In these studies of the phenology of germination of big sagebrush seeds, there were minor differences in the time required to reach various stages of growth and the rate of seedling growth in relation to the substrate the seeds were germinated upon (Table 1). The magnitude of the differences is not large, but the fact that substrate changes as subtle as the ones used could influence germination phenology provides insight into the complex interaction of sagebrush seeds and their seedbed environment.

If the hypocotyl hairs have an important function in juvenile seedling development, the transplanting of the seedlings, which involves pulling the hairs from the substrate and transferring the seedlings to a similar substrate, should influence subsequent seedling survival and perhaps the tropism of the seedlings.

The evidence for substrate interaction is borne out in the study of the influence of seedling transfer on survival and normal seedling tropism (Table 2). For basin big sagebrush there were no significant $(P \leq 0.01)$ differences in seedling survival with transfer of

Table 2. Percentage survival and normal geotropism in seedlings of basin big sagebrush and low sagebrush after transplanting very juvenile seedlings that had been germinated on 3 different substrates. ${ }^{a}$

\begin{tabular}{|c|c|c|c|c|c|}
\hline \multirow[b]{2}{*}{ Substrate } & \multirow[b]{2}{*}{ Treatment } & \multicolumn{2}{|c|}{ Survival } & \multicolumn{2}{|c|}{ Normal geotropism } \\
\hline & & $\begin{array}{l}\text { Basin big } \\
\text { sage- } \\
\text { brush }\end{array}$ & $\begin{array}{l}\text { Low } \\
\text { sage- } \\
\text { brush }\end{array}$ & $\begin{array}{c}\text { Basin big } \\
\text { sage- } \\
\text { brush }\end{array}$ & $\begin{array}{l}\text { Low } \\
\text { sage- } \\
\text { brush }\end{array}$ \\
\hline \multirow{3}{*}{ Fine sand } & & $\ldots \ldots \ldots$ & $\ldots$ & $\%$..... & $\ldots-\ldots$ \\
\hline & control & $100 \mathrm{a}$ & $100 \mathrm{a}$ & $94 \mathrm{a}$ & $96 \mathrm{ab}$ \\
\hline & transferred & $94 \mathrm{a}$ & $77 \mathrm{~cd}$ & $88 \mathrm{~b}$ & $100 \mathrm{a}$ \\
\hline \multirow[t]{2}{*}{ Coarse sand } & control & $100 \mathrm{a}$ & $100 \mathrm{a}$ & $95 \mathrm{a}$ & $91 \mathrm{~b}$ \\
\hline & transferred & $89 \mathrm{ab}$ & $67 \mathrm{~d}$ & $73 \mathrm{c}$ & $72 \mathrm{~d}$ \\
\hline \multirow{2}{*}{$\begin{array}{l}\text { Germination } \\
\text { paper }\end{array}$} & & & & & \\
\hline & $\begin{array}{l}\text { control } \\
\text { transferred }\end{array}$ & $\begin{array}{r}100 \mathrm{a} \\
69 \mathrm{~b} \\
\end{array}$ & $\begin{array}{l}97 \mathrm{ab} \\
84 \mathrm{bc}\end{array}$ & $\begin{array}{l}93 a b \\
72 c \\
\end{array}$ & $\begin{array}{l}98 \mathrm{a} \\
84 \mathrm{c} \\
\end{array}$ \\
\hline \multicolumn{2}{|c|}{ Mean of transferred seeds } & 84 & 76 & 78 & 85 \\
\hline
\end{tabular}

${ }^{a}$ Means within columns followed by the same letter are not significantly different at the 0.01 level of probability as determined by Duncan's Multiple Range Test. Means of transferred seeds for survival and normal geotropism are not significantly different.

seedling from the sand substrate to a similar substrate. When the seedlings were lifted, particles of sand remained attached to some of the hypocotyl hairs. Lifting seedlings from germination paper substrate markedly lowered subsequent survival. Uprooting the hypocotyl hairs interfered with subsequent seedling geotropism in all cases except for low sagebrush seedlings on a fine sand substrate (Table 2). Comparing the mean survival and percentage normal tropism across all substrates resulted in no significant $(P \leq 0.01)$ differences between seedlings of big and low sagebrush. For these very juvenile seedlings the root hairs are less than $0.5 \mathrm{~mm}$ long and restricted to the very tip of the radicle. Root hairs at this stage appear to have a minor role in anchoring the seedling compared to the hypocotyl hairs. The level of abnormal geotropism observed was near complete reversal, in other words, the seedling was lying on the substrate surface and the radicle tip growing up in the air. From the results of this experiment it appears that hypocotyl hairs of sagebrush seedlings do play a role in anchoring juvenile seedlings to the germination substrate; disturbance of seedlings during this stage is detrimental to seedling survival; and the hairs play a role in seedling geotropism. Sheldon (1977) found seeds of several species were sensitive to seed position in relation to the seedbed. Achenes often establish better with the scar of attachment portion

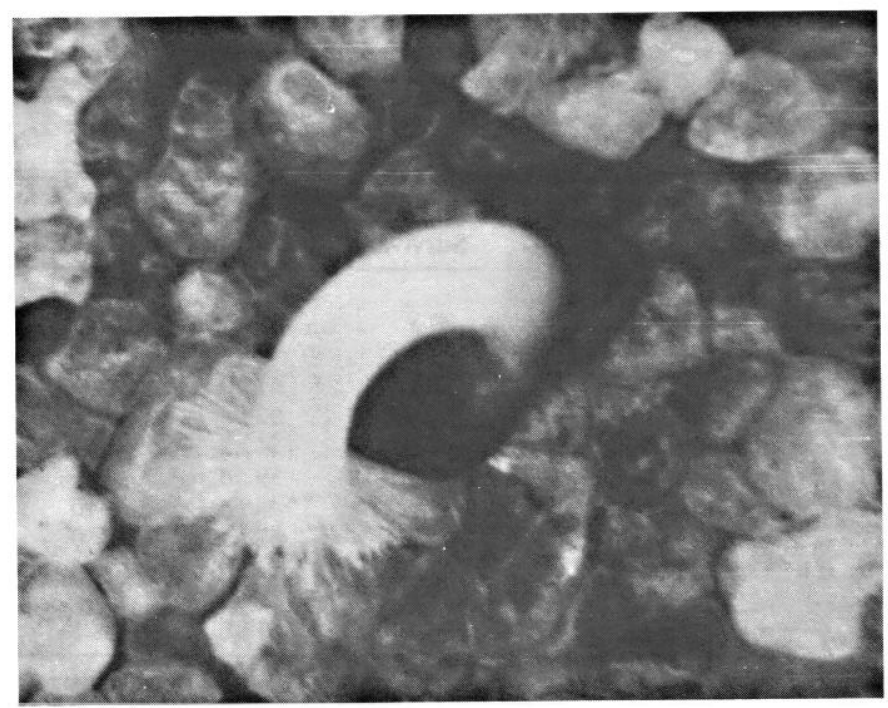

Fig. 6. Hypocotyl hairs of big sagebrush seedling clinging to substrate as radicle penetrates seedbed (light microscope 120X).

of the achene touching the seedbed. Stevens et al. (1986) determined that the pappus of white rubber rabbitbrush (Chrysothamnus nauseosus ssp. albicaulis), played an important part in the wind dispersal of the achene. The achene must land upright with the scar of attachment end pointed downward, touching the seedbed. The hypocotyl hairs of big sagebrush seeds serve the same purpose, but during germination rather than seed dispersal.

Drying big sagebrush seedlings while they were being transferred from one substrate to another greatly reduced survival, but surprisingly there was no significant $(P \leq 0.05)$ increase in mortality from 5 through 60 minutes of drying (Table 3 ). The number of abnormal

Table 3. Percentage survival and normal seedling tropism of basin big sagebrush seedlings dried at $25^{\circ} \mathrm{C}$ for 5,15 , or 60 minutes and then reincubated on moist germination paper in petri dishes.

\begin{tabular}{lcc}
\hline \hline Drying time & Survival & Normal geotropism \\
\hline Minutes & $57 \mathrm{~b}$ & $81 \mathrm{~b}$ \\
0 (transferred) & $29 \mathrm{c}$ & $54 \mathrm{c}$ \\
5 & $28 \mathrm{c}$ & $36 \mathrm{~d}$ \\
15 & $31 \mathrm{c}$ & $39 \mathrm{~d}$ \\
60 & $100 \mathrm{a}$ & $91 \mathrm{a}$ \\
Continuous wet & &
\end{tabular}

${ }^{a}$ Means followed by the same letter, within columns, are not significantly different at the 0.01 level of probability as determined by Duncan's Multiple Range Test.

seedlings increased with drying. There was a big increase in seedlings that did not have upright seedlings rather than true negative tropism (the 2 types were not separated in this experiment).

The 2 types of abnormal seedlings were separated in an experiment where seedlings were subjected to osmotic stress during the transfer process (Table 4). The percentage of seedlings for one type of abnormal seedlings, those with negative tropism, did not differ from treatments that were kept continuously wet with tap water and not transferred for 60 minutes in $-0.6 \mathrm{MPa}$ solutions (Table 4). Seedling survival did decrease with increasing osmotic stress.

From the results of these last experiments, it was apparent that hypocotyl roots played a physical rather than a physiological function in the germination and establishment of sagebrush seedlings. It was also apparent that the tiny sagebrush seedlings were surprisingly resistant to moderate moisture stress, even in very juvenile growth stages. The hypocotyl hairs appeared to be important factors in anchoring sagebrush seedlings in place, but displacement and rupturing the hairs did not appear to be as drastic in Artemisia species as it is in some species of Populus (Polya 1961). 
Table 4. Percentage survival and normal geotropism of basin big sagebrush seedlings transferred to substrates with reduced osmotic potentials for 5, 15, or 60 minutes and then returned to moist germination paper in petri dishes."

\begin{tabular}{ccccc}
\hline \hline \multirow{2}{*}{$\begin{array}{l}\text { Osmotic potential } \\
\text { and duration }\end{array}$} & \multicolumn{3}{c}{ Seedling survival and tropism } \\
\cline { 3 - 5 } MPa & Survival & Abnormal & Negative \\
\hline 0 & continuous & $79 \mathrm{a}$ & $16 \mathrm{e}$ & 5 \\
0 & transfer & $60 \mathrm{~b}$ & $32 \mathrm{~d}$ & 8 \\
-0.03 & 5 minutes & $53 \mathrm{bc}$ & $41 \mathrm{~cd}$ & 6 \\
& 15 minutes & $46 \mathrm{bcd}$ & $52 \mathrm{bc}$ & 2 \\
& 60 minutes & $42 \mathrm{~cd}$ & $54 \mathrm{ab}$ & 4 \\
-0.3 & 5 minutes & $33 \mathrm{~d}$ & $59 \mathrm{ab}$ & 8 \\
& 15 minutes & $41 \mathrm{~cd}$ & $49 \mathrm{bc}$ & 10 \\
-0.6 & 60 minutes & $49 \mathrm{bc}$ & $52 \mathrm{bc}$ & 0 \\
& 5 minutes & $43 \mathrm{~cd}$ & $54 \mathrm{ab}$ & 3 \\
& 15 minutes & $31 \mathrm{~d}$ & $66 \mathrm{a}$ & 3 \\
& 60 minutes & $38 \mathrm{~cd}$ & $61 \mathrm{ab}$ & 1 \\
\hline
\end{tabular}

"Means within columns followed by the same letter are not significantly different at the 0.01 level of probability as determined by Duncan's Multiple Range test. No letters indicate no significant differences.

\section{Literature Cited}

Evans, R.A., J.A. Young, and B.L. Kay. 1974. Germination of winter annual species from a range plant community. Weed Sci. 22:185-187.

Harper, J.L., W.T. Williams, and G.R. Sagar. 1965. The behavior of seeds in soil. Part 1. The heterogeniety of soil surface and its role in determining the establishment of plants from seed. J. Ecol. 53:273-286.
Jacobson, T.L., and B.L. Welch. 1987. Planting depth of "Hobble Creek" mountain big sagebrush seed. Great Basin Natur. 47:497-499.

Polya, L. 1961. Injury by soaking of Populus alba seeds. Nature 189:159-160.

Michel, B.E., and M.E. Kaufman. 1973. The osmotic potential of polyethylene glycol 6000. Plant Physiol. 51:914-916.

Salisbury, E.J. 1942. The reproductive capacity of plants. Bell, London.

Sheldon, J.C. 1977. The behavior of seeds in soils III. The influence of seed morphology and the behavior of seedlings in the establishment of plants from surface lying seed. J. of Ecol. 64:47-67.

Stevens, R., K.R. Jorgenson, J.N. Davis, and S.B. Monson. 1986. Seed pappas and placement influences on white rubber rabbitbrush establishment. pp. 353-357. In: E.D. McArthur and B.L. Welch compilers, Proc. Symposium on the Biology of Artemisia and Chrysothamnus. Gen. Tech. Report. INT 200, Forest Service, USDA, Ogden, Utah.

Wallace, A., W.A. Rhodes, and E.F. Frolich. 1968. Germination behavior of Salsola as influenced by temperature, moisture, depth of planting and gamma radiation. Agron. J. 60:76-78.

Young, J.A., and R.A. Evans. 1973. Mucilaginous seed coats. Weed Sci. 21:52-54.

Young, J.A., R.A. Evans, R.O. Gifford, and R.E. Eckert, Jr. 1970. Germination characteristics of three species of Cruciferae. Weed Sci. 18:41-48.

Young, J.A., R.A. Evans, and B.L. Kay. 1975. Dispersal and germination dynamics of broadleaf filaree, Erodium botrys (Cav.) Bertol. Agron. J. 67:54-57.

Young, J.A., R.A. Evans, and D. Palmquist. 1990. Soil surface characteristics and emergence of big sagebrush seedlings. J. Range Manage. (In Press).

Young, J.A., R.A. Evans, R. Stevens, and R.L. Everett. 1981. Germination of Kochia prostrata seeds. Agron. J. 73:957-961.

\section{Nominations by Petition Are Due December 1, 1991}

This is a formal notice and request by the Nominating Committee for petitions nominating prospective candidates for the elected offices of Second Vice President and Director. Each section is encouraged to submit petitions. The following requirements apply;

(a) Each petition shall name only one candidate for any elected office

(b) Persons nominated must be eligible to hold the elective office for which they are nominated.

(c) A biographical sketch of the prospective candidate must accompany each petition

(d) Each petition shall bear the signature of at least 50 voting members of the society

(e) Petitions shall be submitted to the Chairman of the Nominating Committee not later than December 1, 1991.
The blographical sketch must include but is not limited to:

(a) Full name of prospective candidate

(b) Date and place of birth

(c) Educational background

(d) Current and previous occupation and employment

(e) Society activities in other organizations

(f) Past and present assignments and activities which demonstrate leadership ability

The Nominating Committee solicits your help in this important task of identifying the future leaders of our Society.

Please submit nominations to Raymond D. Mapston, Chairman, Box 507, St. George, Utah 84770 by December 1 st. 